\title{
Sediment phosphorus release sustains nuisance periphyton growth when nitrogen is not limiting
}

\author{
Bradley J. Austin, ${ }^{1 *}$ Violet Eagle, ${ }^{2}$ Michelle A. Evans-White, ${ }^{3}$ J. Thad Scott,${ }^{4}$ Brian E. Haggard ${ }^{1}$ \\ ${ }^{1}$ Arkansas Water Resources Center, University of Arkansas Division of Agriculture, Fayetteville, AR; ${ }^{2}$ Metropolitan State University \\ of Denver, Earth and Atmospheric Science, Denver, CO; ${ }^{3}$ Department of Biological Sciences, University of Arkansas, Fayetteville, \\ AR; ${ }^{4}$ Department of Biology, Baylor University, Waco, TX, USA
}

\begin{abstract}
Nuisance periphyton growth influences the aesthetics, recreation, and aquatic life of waterbodies. Partners Lake is a shallow springfed lake in the headwaters of the Illinois River Watershed in Cave Springs, Arkansas, that experiences nuisance growth of periphyton (i.e., Spirogyra spp.) each year. The molar ratio of dissolved Nitrogen (N) and Phosphorus (P) in the lake water (N:P $\geq 285)$, as well as nutrient limitation assays, suggests that photoautotrophic growth should be P-limited. While the water column lacks sufficient $\mathrm{P}$ to promote phytoplankton growth, the sediments have the ability to release $\mathrm{P}$ to the overlying water; P-flux ranged from $1.63 \mathrm{mg} \mathrm{m}^{-2} \mathrm{~d}^{-1}$ to over $10 \mathrm{mg} \mathrm{m}^{-2} \mathrm{~d}^{-1}$, reaching final $\mathrm{P}$ concentrations of 0.08 to $0.34 \mathrm{mg} \mathrm{L}^{-1}$ in the overlying water of the cores. Sediment $\mathrm{P}$ release is most likely the dominant source of $\mathrm{P}$ for periphyton growth; however, soluble reactive phosphorus concentrations were consistently at or below $0.030 \mathrm{mg} \mathrm{L}^{-1}$ in the lake, suggesting that the periphyton were likely immobilizing $\mathrm{P}$ as quickly as it was released from the

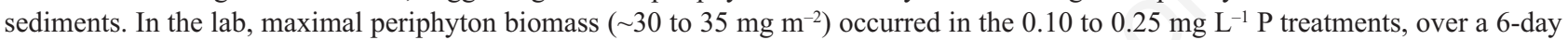
incubation period. Similar levels of growth occurred when lake sediments were the P source, suggesting P released from the sediments is sufficient to support nuisance algal growth. We need to begin managing the legacy P stored in the sediments, in addition to external $\mathrm{P}$ loads, because internal $\mathrm{P}$ can sustain nuisance periphyton biomass when $\mathrm{N}$ is not limiting.
\end{abstract}

\section{INTRODUCTION}

Phosphorus (P) is essential to all life, but at the same time its availability (or lack thereof) under natural conditions tends to limit growth and production in most

Corresponding author: bjaustin@uark.edu

Key words: Sediment P-flux; nutrient limitation; nuisance periphyton growth.

Edited by: Irina Izaguirre, Departamento de Ecología, Genética y Evolución, Universidad de Buenos Aires, Argentina.

Acnowledgements: This work was supported, at least in part, by the NSF REU Program (grant number: DBI 1659857), the Arkansas Water Resources Center through the USGS Water Resources Research Institute Program, the USDA National Institute of Food and Agriculture Hatch Projects, and the UA Division of Agriculture. Any opinions, findings, conclusions, or recommendations expressed in this publication are those of the author(s) and do not necessarily reflect the view of the U.S. Department of Agriculture or Interior.

Received: 30 April 2019.

Accepted: 27 March 2020

This work is licensed under a Creative Commons Attribution NonCommercial 4.0 License (CC BY-NC 4.0).

${ }^{\circ}$ Copyright: the Author(s), 2020

Licensee PAGEPress, Italy

J. Limnol., 2020; 79(3): 210-220

DOI: 10.4081/jlimnol.2020.1913 environments. However, we have used fertilizers (with P) to increase crop yields necessary to support an ever growing population and have historically mismanaged manure $\mathrm{P}$ in animal agriculture landscapes (Ashley et al., 2011; Sharpley et al., 2013). The misuse and overuse of $\mathrm{P}$ in agriculture and limited treatment of wastewater has resulted in a buildup of $\mathrm{P}$ in both terrestrial and aquatic systems, known as legacy P (Jarvie et al., 2013; Sharpley et al., 2013). This legacy $\mathrm{P}$ has the capacity to sustain eutrophic conditions even when external sources have been reduced (Søndergaard et al., 2003, 2013). Eutrophication, can result in water quality problems like increased nuisance periphyton and phytoplankton growth, large swings in dissolved oxygen (Smith et al., 1999), reduced habitat quality for aquatic life (Elosegi and Pozo, 2016), increased occurrence of harmful algal blooms (Zhu et al., 2016), and reduced aesthetic value (DeSimone and Hamilton, 2009).

Many factors influence the growth of photoautotrophs (e.g. light, temperature, grazing etc.) but, $\mathrm{P}$ and nitrogen (N) are often the primary factors (Paerl et al., 2016). The stoichiometric ratio of N:P is an important determinant of which element is limiting growth (Hillebrand and Sommer, 1999). For example, $N$ is typically limiting when the molar $\mathrm{N}: \mathrm{P}$ ratio is less than 20 (9 by mass), $\mathrm{P}$ is limiting when the ratio is greater than 50 (22.6 by mass), and $\mathrm{N}$ and $\mathrm{P}$ are co-limiting when molar ratios are between 20 and 50 (Guildford and Hecky, 2000); however, the magnitude of the concentrations may limit the importance of the supply ratios. Photoautotrophs can be limited by $\mathrm{N}$ or $\mathrm{P}$ independently or even co-limited 
(Ludwig et al., 2012; Müller and Mitrovic, 2015), and the limiting nutrient can shift seasonally especially in lakes, both natural and manmade (Maberly et al., 2002).

While $\mathrm{N}$ or $\mathrm{P}$ can limit photoautotroph growth in aquatic systems, reducing external $\mathrm{P}$ loading has been proposed as the most effective means for controlling eutrophication in freshwater systems (Schindler et al., 2008). However, internal loading of nutrients from the sediments can also be an important source of nutrients for primary producers (e.g., see Steinman et al. 2009; Grantz et al. 2014; Lasater and Haggard 2017). Phosphorus is released from bottom sediments through desorption to maintain an equilibrium concentration (Reddy et al., 1995; Haggard et al., 2007) and through changing redox potential at the sediment-water interface (Mortimer, 1971). Additionally, photoautotrophs in the water column can influence the environmental conditions overlying lake sediments to promote further P release from the sediments (McCarty, 2020). This P from the sediments can contribute to eutrophication for decades, even after external sources have been reduced (Søndergaard et al., 2003, 2013).

Partners Lake is a 2.1 ha impoundment near Cave Springs, Arkansas (Fig. 1), managed by the Illinois River
Watershed Partnership (IRWP). The watershed for the lake is small (10.3 ha) with $75 \%$ forested and $21 \%$ influenced by human development (agriculture and urbanization). However, the recharge area for the cave system that flows in to the lake is larger (2400 ha), of which, $92 \%$ of the area is influenced by human development. Due to the high level of human development in the recharge area, water entering the lake from the cave system has relatively high dissolved inorganic $\mathrm{N}\left(\sim 5 \mathrm{mg} \mathrm{L}^{-1}\right)$, but relatively low soluble reactive $\mathrm{P}\left(\mathrm{SRP}=0.03 \mathrm{mg} \mathrm{L}^{-1}\right)$ (www.adeq.state.ar. us/techsvs/env_multi_lab/water_quality; date acquired 10/1/2019), resulting in a DIN:SRP molar ratio of 355.

Nuisance periphyton blooms commonly occur in Partners Lake during the growing season (i.e., March $1^{\text {st }}$ through October $31^{\text {st }}$ ), consisting primarily of Spirogyra spp. (W.R. Green, personal communication), a filamentous green algae. Periodically, the periphyton detaches and floats to the surface forming a dense floating mat or "metaphyton" (Stevenson, 1996; Scott et al., 2007; Fig. 1). However, other than metaphyton surface scums, the lakes water column is relatively clear suggesting that phytoplankton is likely limited. Historically, copper sulfate $\left(\mathrm{CuSO}_{4}\right)$ has been used to control the nuisance

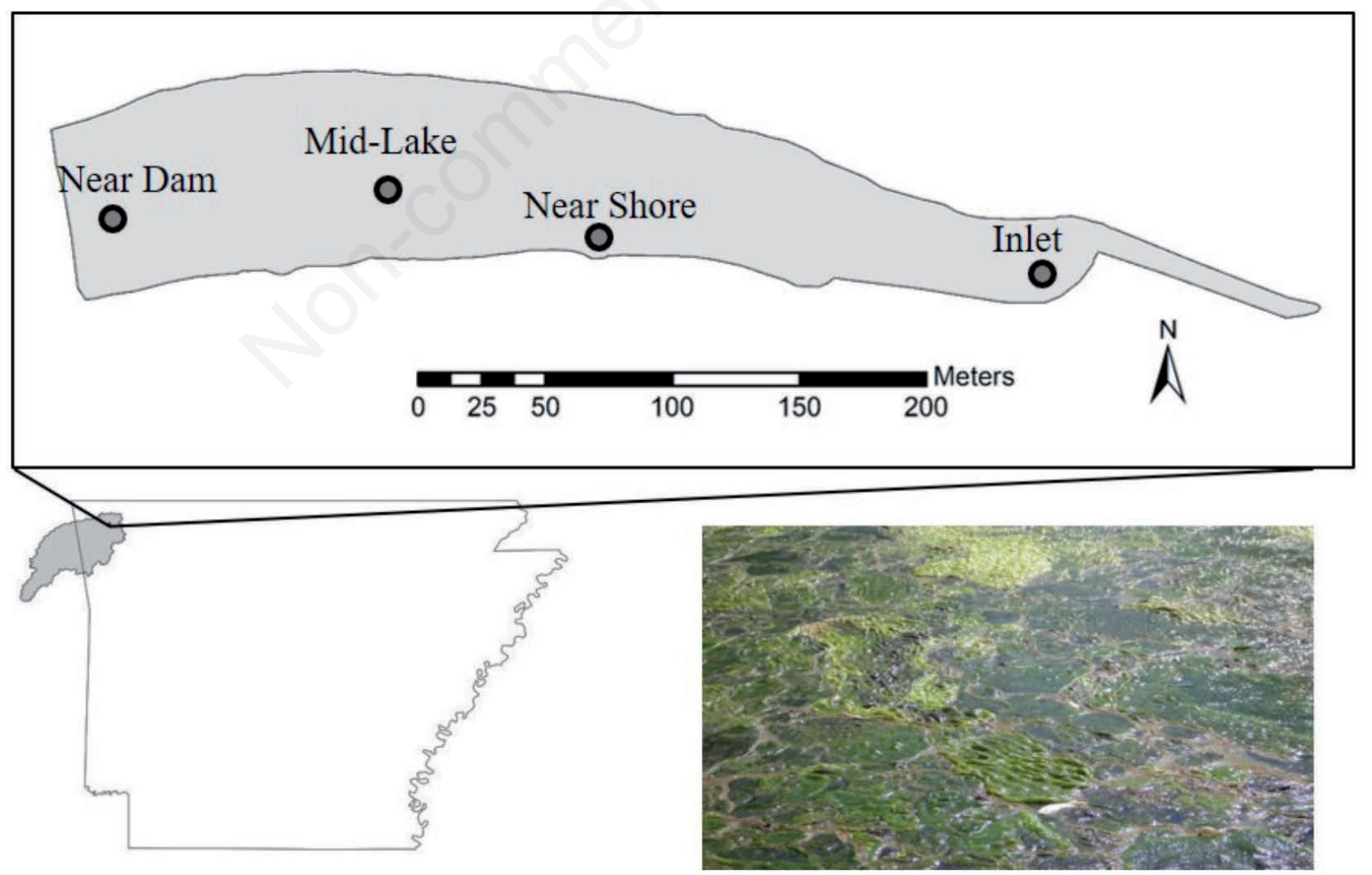

Fig. 1. Map of sample locations within Partner's Lake in Northwest Arkansas, image in the lower right corner is of a surface metaphyton mat of Spirogyra spp. from Partner's Lake. 
algal blooms, with anywhere from 7 to $37 \mathrm{~L} \mathrm{ha}^{-1}$ of $\sim 18 \%$ by volume $\mathrm{CuSO}_{4}$ being applied to the lake at approximately monthly intervals, depending on the severity of the bloom.

Despite the apparent $\mathrm{P}$ limiting conditions of the water entering Partners Lake, nuisance periphyton and metaphyton blooms persist in the lake each spring and summer. The goals of this study were to understand which nutrient(s) limit photoautotrophs in Partners Lake and to determine the sources of $\mathrm{P}$ to the lake. Specifically, due to the stoichiometric imbalance of $\mathrm{N}$ and $\mathrm{P}$ in the water column, we hypothesized that periphyton and phytoplankton would be P-limited, predicting that photoautotrophs would respond to nutrient treatments with $\mathrm{P}$ added in situ and in the greenhouse. Both in situ and greenhouse studies were conducted to examine nutrient limitation of photoautotrophs in Partners Lake. The in situ study was used to examine nutrient limitation of periphyton for this study we predicted that periphyton biomass would be greater on nutrient treatments containing $\mathrm{P}$ than treatments without $\mathrm{P}$. The greenhouse study was used to examine nutrient limitation of phytoplankton, for this study we predicted that treatments with $\mathrm{P}$ added (both $\mathrm{P}$ and $\mathrm{N}+\mathrm{P}$ ) would have greater biomass than the treatments without $\mathrm{P}$ added.

Since the water column is P-limited, where is the $\mathrm{P}$ coming from to support nuisance periphyton growth? Based on previous research suggesting that $P$ from the sediments can contribute to eutrophication of lakes, we hypothesized that the bottom sediments of Partner's Lake are a significant source of P. We measured P-release in sediment cores collected from across the lake to quantify how much $\mathrm{P}$ is leaving the sediment. We predicted that $\mathrm{P}$ concentrations in the overlying water of the sediments would increase under both aerobic and anaerobic conditions.

We also hypothesized that the $\mathrm{P}$ leaving the sediments would be sufficient to support nuisance periphyton growth. A third nutrient limitation study was conducted in the greenhouse to examine the effect of sediment Pflux on periphyton growth. For this experiment, we predicted that the P released from the lake sediments would maximize periphyton growth.

\section{METHODS}

\section{Water quality monitoring}

Water samples were collected from $0.25 \mathrm{~m}$ below the surface in triplicate, at a semi-monthly interval from April through August of 2017 to determine how water chemistry and phytoplankton biomass varied across the lake. Three sites were sampled each time, one near the inlet, another at mid-lake, and the third near the dam (Fig.
1). To examine the variability in water chemistry and phytoplankton biomass in the water column, water samples were also collected at $2.5 \mathrm{~m}$ or roughly $0.5 \mathrm{~m}$ above the bottom at the mid-lake and dam sites on April $19^{\text {th }}$ and May $9^{\text {th }} 2017$. During these two sample periods, temperature profiles at the mid lake and dam sites showed that the lake was not thermally stratified. Additionally, previous work in July of 2013, suggests that the lake remains unstratified even into the summer months $(\mathrm{N}$. Hardiman, personal communication). The bottom of the lake was visible from the surface during every sampling event, suggesting that the photic and Secchi depths were greater than the lake depth.

Sample bottles were stored in a cooler on ice and delivered to the Arkansas Water Resources Centers (AWRC) certified Water Quality Laboratory within 4 hours after collection. Upon arrival to the laboratory, water samples were split, filtered, and acidified as necessary for the determination of nitrate+nitrite as $\mathrm{N}$ (hereinafter $\left.\mathrm{NO}_{3}-\mathrm{N}\right)$, ammonium as $\mathrm{N}\left(\mathrm{NH}_{4}-\mathrm{N}\right)$, total $\mathrm{N}$ (TN), soluble reactive $\mathrm{P}$ (SRP), total $\mathrm{P}$ (TP), and phytoplankton biomass measured as chlorophyll- $a$ (CHLa). Analytes were measured following EPA and standard methods for water quality analysis, which can be found at the AWRC's website (https://arkansas-watercenter.uark.edu/: acquired 3/17/20).

\section{Nutrient limitation}

Nutrient limitation was evaluated for both periphyton and phytoplankton growing at the inlet, mid-lake, and dam sites (Fig. 1). Nutrient diffusing substrata (NDS) were deployed in lake to examine nutrient limitation of periphyton growth (Matlock et al., 1998; Scott et al., 2005) while cubitainers were incubated in the greenhouse to examine nutrient limitation of phytoplankton growth. In both experiments there were four treatments $(\mathrm{n}=8 /$ treatment), including a control (no nutrients added), $+\mathrm{P}\left(\mathrm{K}_{2} \mathrm{HPO}_{4}-\mathrm{P}\right.$ at $0.5 \mathrm{mg} \mathrm{L}^{-1}$ as $\left.\mathrm{P}\right),+\mathrm{N}\left(\mathrm{KNO}_{3}-\mathrm{N}\right.$ at 5.0 $\mathrm{mg} \mathrm{L}^{-1}$ as $\left.\mathrm{N}\right)$, and $\mathrm{N}+\mathrm{P}\left(\mathrm{K}_{2} \mathrm{HPO}_{4}-\mathrm{P}\right.$ at $0.5 \mathrm{mg} \mathrm{L}^{-1}$ as $\mathrm{P}$ and $\mathrm{KNO}_{3}-\mathrm{N}$ at $5.0 \mathrm{mg} \mathrm{L}^{-1}$ as $\mathrm{N}$ ). $\mathrm{N}$ and $\mathrm{P}$ were added to each treatment at concentrations that would increase each above background conditions and produce a stoichiometrically balanced N:P molar ratio of 22:1 (or 10:1 by mass) in the $\mathrm{N}+\mathrm{P}$ treatment.

Nutrient diffusing substrates are a system that allows the nutrients in the treatment solution to diffuse across a glass fiber filter (i.e. substrate) promoting growth of photoautotrophs. The treatment solutions were in $250-\mathrm{ml}$ bottles, bottle openings were covered with $45-\mathrm{mm}$ diameter, $0.45-\mu \mathrm{m}$ pore size membrane filter and then with a glass fiber filter (Whatman ${ }^{\circledR}$ 934-AH, 37-mm, $1.5-\mu \mathrm{m}$ pore size) to serve as a substrate for periphyton growth (Matlock et al., 1998; Scott et al., 2005). Bottle caps with a $2.5-\mathrm{cm}$ diameter hole were then screwed on 
to the bottles to hold the filters in place. Aluminum screen $\left(\sim 1-\mathrm{mm}^{2} \mathrm{mesh}\right)$ was placed over the caps to prevent grazers from eating the periphyton growing on the filters.

The bottles and NDS were attached to deployment racks in 8 rows of 4 in a semi-random block design. Each rack consisted of a 1.2-m x 1.8-m cattle panel, secured to two $0.15-\mathrm{m}$ diameter $\mathrm{x} 1.8-\mathrm{m}$ long sealed PVC pipes for buoyancy. Cinder blocks were used to anchor each rack at one of the three sites along the length of the lake. The glass fiber filters on the bottles sat perpendicular to the water's surface at $\sim 0.1 \mathrm{~m}$ below the surface. A detailed description and diagram of the deployment rack and NDS bottles can be found in Matlock et al. (1998).

Nutrient diffusing substrates were deployed for 11 days (June $8^{\text {th }}$ to $19^{\text {th }} 2017$ ) before harvesting. Upon retrieval the glass fiber filters were placed into pre-labeled $15-\mathrm{mL}$ centrifuge tubes. The centrifuge tubes were stored on ice in the dark and delivered to the laboratory within 4 $\mathrm{h}$ of collection, where $7 \mathrm{~mL}$ of $90 \%$ acetone was added to each, they were then allowed to steep at $-20^{\circ} \mathrm{C}$ for at least $24 \mathrm{hr}$ before being analyzed for phaeophytin corrected CHL- $a$ fluorometrically using a Turner Design Trilogy fluorometer (APHA 2014; \#10200H)

At each site, 32 1-L opaque cubitainers were filled with water just below the surface $(\sim 0.1 \mathrm{~m})$, taking care to avoid collecting clumps of metaphyton, and then returned to the greenhouse for nutrient enrichment experiments on June $6^{\text {th }} 2017$. Additionally, 5 1-L samples were collected at each site to provide initial nutrient and phytoplankton biomass conditions at the start of the experiment. Once in the greenhouse nutrients were added to the water in the cubitainers to achieve the desired treatment concentrations, listed earlier. The cubitainers were then incubated under ambient light conditions, in water baths to buffer temperature fluctuations.

During incubation, each cubitainer was shaken and vented to allow for gas exchange daily and to dislodge any potential wall growth inside of the cubitainers, although no wall growth was detected throughout the experiment. On days 3 and 6 of the incubation, $200 \mathrm{~mL}$ of water was filtered through Whatman GF/F glass fiber filters ( $25-\mathrm{mm}$ diameter, $1.0-\mu \mathrm{m}$ pore size). To avoid having to account for a dilution effect on day 6, replacement water was not added after filtering on day 3 . Samples collected on day 3 of the experiment were used to check the progress of the experiment and were not used in analyses. Filters were placed in to 15 -ml centrifuge tubes with $7 \mathrm{ml}$ of $90 \%$ acetone and then allowed to steep at $-20 \mathrm{C}$ for at least $24 \mathrm{~h}$ before analyzing for CHL- $a$ following methods described earlier.

\section{Sediment phosphorus flux}

Sediment P-flux was measured at each of the three sites plus an additional near shore site, in May 2017 (Fig.
1). A manual gravity corer with acrylic plastic tubes (inside area $0.0046 \mathrm{~m}^{2}$, height $0.6 \mathrm{~m}$ ) was used to collect intact sediment cores from each of the sites. Sediment cores were transported back to the laboratory and set up for the P-flux study the same day collected.

The volume of overlying water in each sediment core was adjusted to $1 \mathrm{~L}$. Cores were then wrapped with Reflectix $^{\odot}$ to shade out ambient light, and then incubated at room temperature $\left(\sim 22^{\circ} \mathrm{C}\right)$. Three cores from each site were incubated under aerobic conditions (bubbled with air), three additional cores from the dam and mid-lake sites were incubated under anaerobic conditions (bubbled with ultra-pure $\mathrm{N}_{2}$ gas). Partners Lake is relatively shallow (maximum depth $=3 \mathrm{~m}$ ) and, for this reason, it is not normally anaerobic; however, shallow lakes may temporarily stratify reducing dissolved $\mathrm{O}_{2}$, creating anaerobic conditions near the sediment surface under extremely calm conditions. In light of this, both aerobic and anaerobic P-flux rates were measured for sediments from the mid-lake and dam sites.

Water samples $(50 \mathrm{~mL})$ were collected from each core at a 1- to 2-day interval for two weeks. Water samples were collected from mid-depth of the overlying water, filtered $(0.45-\mu \mathrm{m})$, and acidified with concentrated $\mathrm{HCl}$. Water removed from each core was replaced with prefiltered $(0.45-\mu \mathrm{m})$ lake water. Water samples and replacement lake water were analyzed for SRP using the automated ascorbic acid reduction method (APHA, 2014; \#4500-P F).

Measured SRP concentrations in the overlying water of each core, were converted to $P$ mass and then corrected for the mass of $P$ removed and added during each sample period. Sediment P-flux $\left(\mathrm{mg} \mathrm{m}^{-2} \mathrm{~d}^{-1}\right)$ was calculated for each sediment core as the linear rate of change in $P$ mass in the overlying water as a function of time $\left(\mathrm{mg} \mathrm{d}^{-1}\right)$ and divided by the internal core area $\left(0.0046 \mathrm{~m}^{2}\right)$ (Lasater and Haggard, 2017). Linear regressions were used to define the slope of the relationship between $\mathrm{P}$ mass in the overlaying water and time for each core, with the slope representing the P-flux.

\section{Mesocosm periphyton limitation}

A mesocosm experiment was conducted to evaluate the effect of increasing $\mathrm{P}$ concentrations and sediment $\mathrm{P}$ release on periphyton growth. Ninety-six unglazed hexagonal tiles (surface area $0.00051 \mathrm{~m}^{2}$ ) were suspended $0.05 \mathrm{~m}$ below the water's surface in Partners Lake on a floating tray for one week to colonize with periphyton. Colonized tiles were returned to the greenhouse, where they were randomly selected and evenly divided, into one of 11 treatment/experimental units or processed for initial CHL- $a$ content ( 8 tiles per experimental unit and 8 tiles for measuring initial biomass).

Nine of the 11 experimental units consisted of clear 
containers (3.86-L Rubbermaid ${ }^{\circ}$ plastic jars) filled with 1-L of filtered $(0.45-\mu \mathrm{m})$ lake water $\left(\mathrm{NO}_{3}-\mathrm{N}=4.9 \mathrm{mg} \mathrm{L}^{-}\right.$ ${ }^{1}$ and $\mathrm{SRP}=0.016 \mathrm{mg} \mathrm{L}^{-1}$ ) and amended with $\mathrm{KH}_{2} \mathrm{PO}_{4}$ to achieve a gradient of added SRP (no additional $\mathrm{P}$ added, $0.01,0.025,0.05,0.1,0.25,0.5,0.75$, and $1.0 \mathrm{mg} \mathrm{L}^{-1} \mathrm{PO}_{4^{-}}$ $\mathrm{P})$, at the time tiles were added. In the two remaining experimental units, $25 \mathrm{~g}$ of dried sediment from the dam or mid-lake site was added to the filtered lake water to serve as the P source. Sediments were added to the lake water 4 days prior to the start of the experiment to allow $\mathrm{P}$ in the sediments to equilibrate with the overlying water (Brennan et al., 2017). Mean aerobic SRP-release rates for sediments, determined in the sediment P-flux study, were used to estimate initial SRP concentrations in the two sediment treatments. The initial SRP concentration was calculated as the product of the area corrected rate and the number of days the sediment was allowed to equilibrate.

The 8 tiles for determining initial CHL- $a$ content were placed into $50-\mathrm{mL}$ centrifuge tubes with $20 \mathrm{~mL}$ of $90 \%$ acetone (Johnson et al., 2009). CHL- $a$ was extracted from the surface of the tiles by steeping in the dark at $-20^{\circ} \mathrm{C}$ for at least $24 \mathrm{~h}$, extracted CHL- $a$ was then analyzed fluorometrically, as described previously.

All treatments were incubated in a water bath to buffer temperature fluctuations under ambient diel light conditions in the greenhouse. After the first three days, 20 $\mathrm{mL}$ of water was collected from each of the treatments, filtered $(0.45-\mu \mathrm{m})$, acidified, and then analyzed for SRP. Then all treatments were returned to starting volumes using filtered lake water, and $\mathrm{KH}_{2} \mathrm{PO}_{4}$ was added to the non-sediment treatments to return them to initial SRP concentrations. The study concluded at 6 days, at this time all tiles were carefully transferred from their treatments into $50-\mathrm{mL}$ centrifuge tubes with $20 \mathrm{~mL}$ of $90 \%$ acetone (Johnson et al., 2009). CHL- $a$ was extracted from the surface of the tiles by steeping in the dark at $-20^{\circ} \mathrm{C}$ for at least $24 \mathrm{~h}$, extracted CHL- $a$ was then analyzed fluorometrically, as described previously.

\section{Data analysis}

Water chemistry parameters were averaged across the triplicate samples collected during each sample date and then were assessed for variability between sites, and between sample periods using two one-way analysis of variance (ANOVA), an additional one-way ANOVA was used to compare water chemistry parameters measured near the surface versus near the bottom at the dam and mid-lake sites. Least significant difference (LSD) was used to compare $(\mathrm{P}<0.05)$ treatment means. All data was assessed for normality and equal variance and $\log$ transformed if they did not meet these assumptions prior to statistical analysis.

A two-way ANOVA was used to test whether algal biomass was limited by P (i.e. biomass significantly greater in treatments containing $\mathrm{P}$ than in treatments without), by $\mathrm{N}$ (i.e. biomass significantly greater in treatments containing $\mathrm{N}$ than in treatments without), or co-limited by $\mathrm{N}$ and $\mathrm{P}$ (i.e. represented by a significant interaction term in the ANOVA, $\mathrm{P}<0.05$ ). All data was assessed for normality and equal variance and log transformed if they did not meet these assumptions prior to statistical analysis. LSD was used to compare $(\mathrm{P}<0.05)$ treatment means for the nutrient limitation experiments. For the nutrient limitation assays, limitation of growth by either $\mathrm{N}$ or $\mathrm{P}$ or both $\mathrm{N}$ and $\mathrm{P}$ (co-limitation; defined by a significant interaction term) was assessed for each site independently.

An unbalanced-two-way ANOVA was used to compare final SRP concentrations and P-flux across cores collected from four locations (dam, mid, inlet, near-shore) and between aerobic and anaerobic cores collected from dam and mid lake locations. All data was assessed for normality and equal variance and log transformed if they did not meet these assumptions prior to statistical analysis. Least significant difference (LSD) was used to compare $(\mathrm{P}<0.05)$ treatment means.

For the mesocosm experiment, individual containers served as the experimental units. CHL- $a$ content in the Pamended treatments were plotted versus SRP concentration and were fitted to an exponential growth curve. The CHL- $a$ content from the two sediment treatments was plotted versus their estimated initial $\mathrm{P}$ concentrations in the same space as the P-amended treatments. Sediment treatment CHL- $a$ content occurring within the $95 \%$ confidence interval of the exponential growth curve were viewed as not significantly different from the modeled line.

\section{RESULTS}

\section{Water chemistry}

SRP concentrations across all water samples ranged from below detection $\left(\mathrm{MDL}=0.004 \mathrm{mg} \mathrm{L}^{-1}\right)$ to $0.037 \mathrm{mg}$ $\mathrm{L}^{-1}$. Mean SRP concentrations were greatest at the inlet and decreased by more than $50 \%$ at the sites further down the lake $\left(\mathrm{F}_{2,10}=29.57, \mathrm{P}<0.001\right)$. Measured SRP concentrations varied through time, with the greatest concentrations in May and August, and the lowest in June and July $\left(\mathrm{F}_{5,10}=4.55, \mathrm{P}=0.020\right.$; Fig. $\left.2 \mathrm{~A}\right)$, whereas SRP was not variable throughout the water column at the mid-lake and dam sites $\left(\mathrm{F}_{1,6}=0.32, \mathrm{P}=0.590\right)$. Total $\mathrm{P}$ concentrations were not different between sites $\left(\mathrm{F}_{2,10}=0.45, \mathrm{P}=0.650\right)$ or across sample periods $\left(\mathrm{F}_{5,10}=1.73, \mathrm{P}=0.215\right.$; Fig. $\left.2 \mathrm{~B}\right)$, but $\mathrm{TP}$ at the sites shifted from being dominated by SRP at the inlet (SRP $\sim 80 \%$ of TP) to mostly particulate and dissolved organic $\mathrm{P}$ at the dam (SRP 30\% of TP). Lake 
$\mathrm{NO}_{3}-\mathrm{N}$ concentrations decreased significantly from the inlet to the dam $\left(\mathrm{F}_{2,10}=11.90, \mathrm{P}=0.002\right)$, with the inlet having greater concentrations than the mid-lake and dam sites $(\mathrm{P}=0.002)$, but no difference between mid-lake and dam $(\mathrm{P}=0.744) . \mathrm{NO}_{3}-\mathrm{N}$ was also variable through time $\left(\mathrm{F}_{5,10}=8.33, \mathrm{P}=0.002\right)$, with the greatest concentrations in June and the lowest in April (Fig. 2C). $\mathrm{NO}_{3}-\mathrm{N}$ concentrations were not different throughout the water column at the mid-lake and dam sites $\left(\mathrm{F}_{1,6}=0.26\right.$, $\mathrm{P}=0.627$ ).
In contrast, $\mathrm{NH}_{4}-\mathrm{N}$ was very low in most of the samples collected. Mean $\mathrm{NH}_{4}-\mathrm{N}$ concentrations across sites, sample periods, and depths was $0.01 \mathrm{mg} \mathrm{L}^{-1}$, with $75 \%$ of the measured samples at or below the method detection limit $\left(\mathrm{MDL}=0.01 \mathrm{mg} \mathrm{L}^{-1}\right)$. With the majority of data at or below detection, no statistical comparisons were performed for $\mathrm{NH}_{4}-\mathrm{N}$. Most of the $\mathrm{TN}$ measured in the lake was in the form of $\mathrm{NO}_{3}-\mathrm{N}(\sim 95 \%$ of $\mathrm{TN})$. So, like $\mathrm{NO}_{3}-\mathrm{N}, \mathrm{TN}$ concentrations were greatest at the inlet and lowest at the dam $\left(\mathrm{F}_{2,10}=10.40, \mathrm{P}=0.004\right)$, and fluctuated
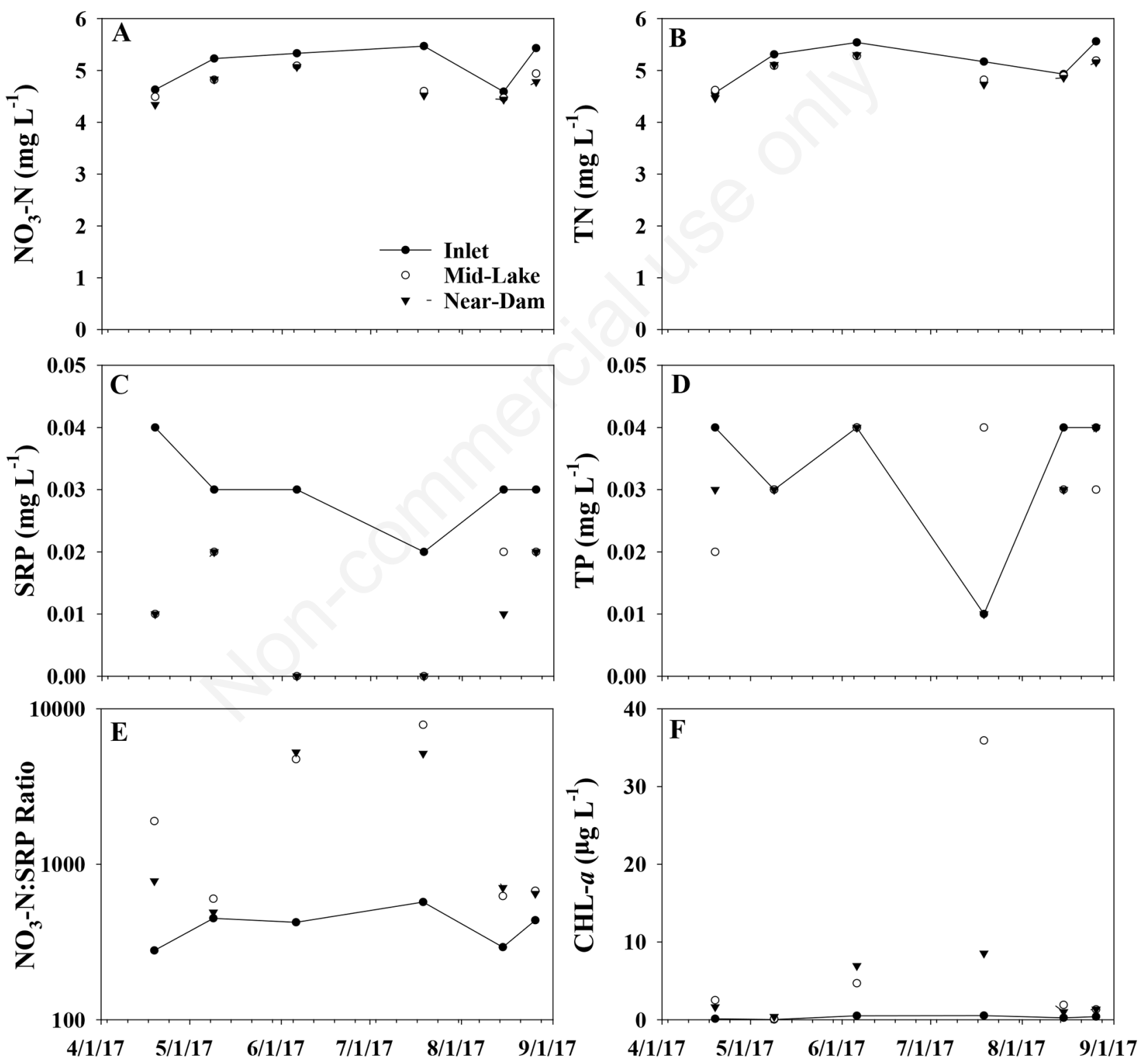

\section{Sample Date}

Fig. 2. Nitrate-N $\left(\mathrm{NO}_{3}-\mathrm{N}\right)(\mathrm{A})$, total $\mathrm{N}(\mathrm{TN})(\mathrm{B})$, soluble reactive phosphorus (SRP) (C), total P (TP) (D), $\mathrm{NO}_{3}-\mathrm{N}: \mathrm{SRP}$ (molar) (E), and chlorophyll- $a(\mathrm{CHL}-a)$ (F) measured at surface from the inlet, mid-lake, and near the dam during the 2017 growing season. 
over time $\left(\mathrm{F}_{5,10}=29.82, \mathrm{P} 0.001\right)$, with mean concentrations greatest in June and lowest in April (Fig. 2D). The mean $\mathrm{TN}$ for water samples collected near the bottom was not significantly different from water collected from near the surface of the water column $\left(\mathrm{F}_{1,6}=0.82, \mathrm{P}=0.384\right)$

Within Partners Lake, the molar $\mathrm{NO}_{3}-\mathrm{N}: \mathrm{PO}_{4}-\mathrm{P}$ (hereinafter DIN:SRP) was greatest in June and July (DIN:SRP > 4000) and below 1000 during the other sample periods $\left(\mathrm{F}_{5,10}=3.51, \mathrm{P}=0.043\right)$ and did not vary across sites $\left(\mathrm{F}_{2,10}=3.55, \mathrm{P}=0.068\right.$; Fig. $\left.2 \mathrm{E}\right)$ or with depth $\left(\mathrm{F}_{1,6}=0.33, \mathrm{P}=0.587\right)$. The molar ratio of TN:TP ranged from 250 to 990 with a mean ratio of 390 . Molar TN:TP was did not vary across sites $(\mathrm{P}=0.619)$, over time $(\mathrm{P}=0.116)$, or with depth $(\mathrm{P}=0.234)$. Phytoplankton CHL-a concentrations were below $3.5 \mu \mathrm{g} \mathrm{L}^{-1}$ in roughly $70 \%$ of the surface samples, but near the bottom it reached $517 \mu \mathrm{g} \mathrm{L}^{-1}$. This high value from near the bottom was the result of collecting metaphyton in the mid-lake water samples in April of 2017, and does not necessarily reflect phytoplankton biomass; however, these differences were not statistically significant $\left(F_{1,6}=0.99, P=0.359\right)$, so they were not excluded from analyses. Chlorophyll-a concentrations in the surface samples did not vary significantly between sites $(\mathrm{P}=0.255)$ or between sample periods $(\mathrm{P}=0.214$; Fig. 2F). Additionally, phytoplankton biomass (i.e. CHL-a) in the surface water and DIN:SRP were positively correlated $(\mathrm{R}=0.867, \mathrm{P}<0.0001)$, this was likely due to increased phytoplankton biomass depleting SRP in the water column, thus increasing the DIN:SRP ratio.

\section{Nutrient limitation}

Periphyton nutrient limitation assays showed no effect of nutrient treatment on periphyton growth at the inlet and mid-lake sites. Metaphyton covered the NDS at these two sites, which likely limited light and periphyton growth on the substrates and resulted in no treatment effects. However, at the dam site, nutrient limitation assays showed that periphyton growth was P-limited $\left(\mathrm{F}_{3,28}=4.62\right.$; $\mathrm{P}=0.010$; Fig. 3A).

For phytoplankton nutrient limitation assays, results varied by site. In the inlet phytoplankton was co-limited by $\mathrm{N}$ and $\mathrm{P}$ (Fig. 3B). Whereas, nutrient limitation assays for water collected at mid-lake and near the dam suggested phytoplankton growth was P-limited (Fig. 3B).

\section{Sediment phosphorus flux}

In the sediment P-flux experiment, the linear relationships between SRP mass in the overlying water and time were positive in all of the cores and the slope of the line for each treatment was significantly different than zero (Tab. 1). There was no difference in the final SRP concentrations in the overlying water of cores collected from the different regions of the lake $\left(\mathrm{F}_{3,17}=1.96\right.$, $\mathrm{P}=0.174)$. However, final SRP concentrations in the overlying water of the anaerobic cores were greater than in the aerobic cores $\left(\mathrm{F}_{1,17}=5.46, \mathrm{P}=0.038\right.$; Fig. $\left.4 \mathrm{~A}\right)$.

The mean aerobic P-flux ranged from $1.63 \mathrm{mg} \mathrm{m}^{-2} \mathrm{~d}^{-1}$ near-shore, to $6.6 \mathrm{mg} \mathrm{m}^{-2} \mathrm{~d}^{-1}$ at the dam. There was no difference in P-flux between sites and treatments $\left(\mathrm{F}_{5,17}=2.03, \mathrm{P}=0.146\right.$; Fig. 4B $)$.

\section{Mesocosm periphyton limitation}

In the greenhouse mesocosm study, periphyton growth was related to increasing $P$ concentrations in the incubation water. At the end of the 6-d incubation period, periphyton CHL- $a$ content increased across the SRP concentration gradient, achieving maximum biomass in
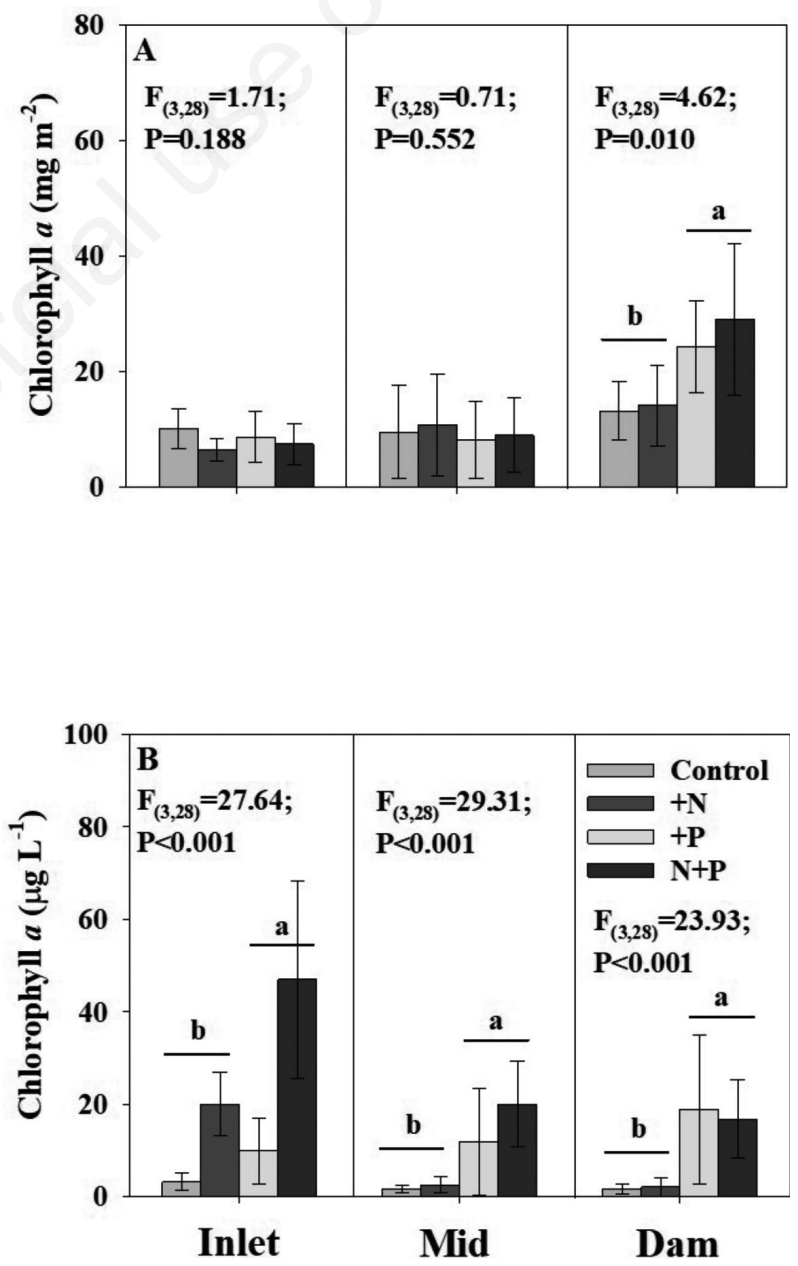

Fig. 3. Nutrient limitation assays (chlorophyll- $a$ biomass, mean $\pm 1 \mathrm{SE}$ ) for periphyton (A) and phytoplankton (B) biomass at each of the sites. Statistics reflect comparisons between treatments at each site (not across sites), different letters denote significant difference (LSD, $\mathrm{P}=0.05$ ) between treatments with $\mathrm{P}$ added and those without $\mathrm{P}$ at each site. 

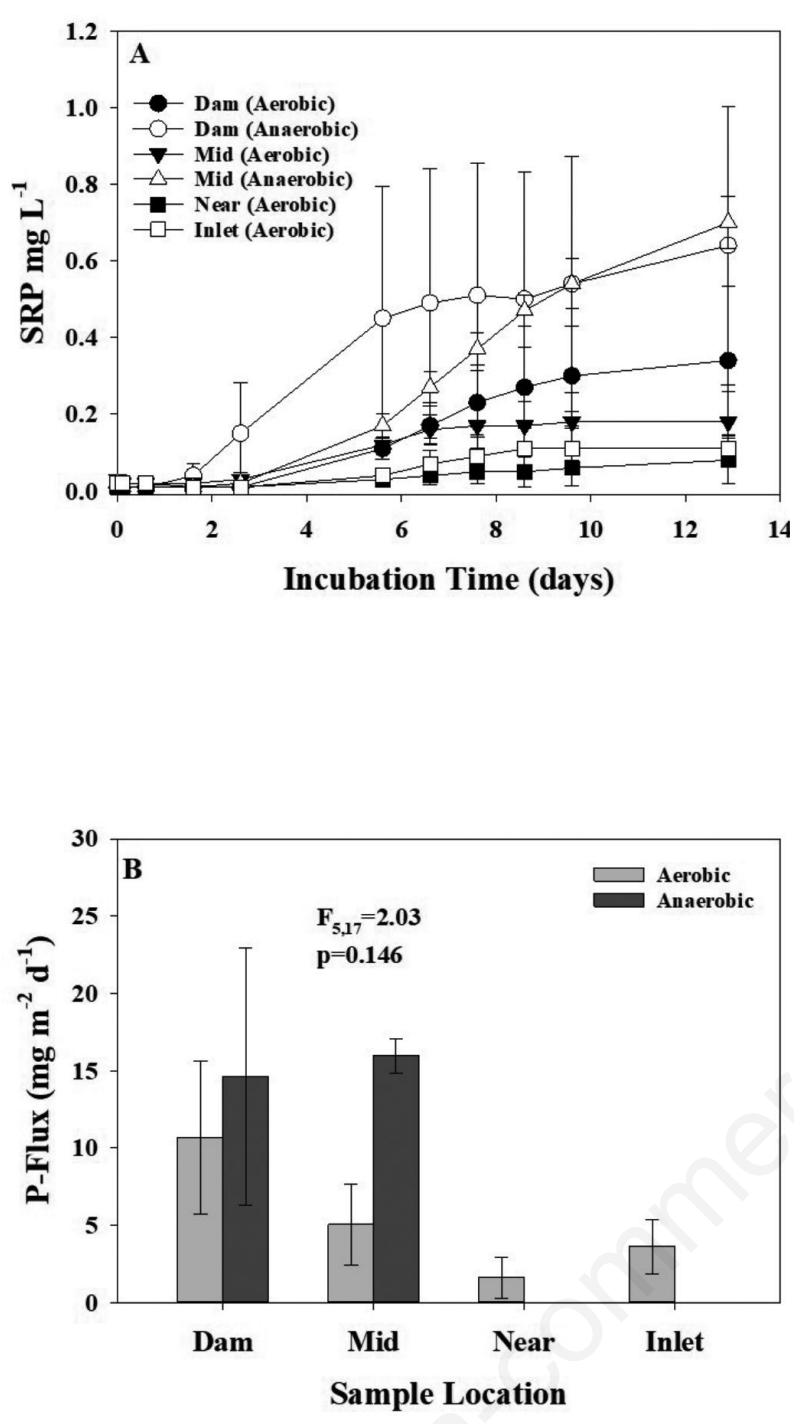

Fig.4. Mean soluble reactive phosphorus (error bars $= \pm 1 \mathrm{SE}$ ) measured over time in the overlying water of cores collected from Partners Lake (A). Mean phosphorus flux (error bars $= \pm$ $1 \mathrm{SE}$ ) from each sample site (B). Statically significant F statistic is for the comparison of P-flux under aerobic and anaerobic conditions for the mid-lake cores only. treatments with $0.10 \mathrm{mg} \mathrm{L}^{-1}$ or greater SRP concentrations (Fig. 5). This change in periphyton CHL- $a$ across the SRP gradient reflects an exponential growth curve, where above a certain point $\left(0.10\right.$ to $\left.0.25 \mathrm{mg} \mathrm{L}^{-1}-\mathrm{P}\right) \mathrm{CHL}-a$ no longer increases. CHL- $a$ content plateaued at approximately 30 to $35 \mathrm{mg} \mathrm{m}^{-2}$.

Periphyton biomass supplemented with SRP from lake sediments was compared to periphyton CHL- $a$ biomass along the SRP gradient. Mean periphyton CHL- $a$ content in the near-dam sediment treatment was not significantly different than periphyton CHL- $a$ content in the treatments with $0.10 \mathrm{mg} \mathrm{L}^{-1}$ or more SRP; however, CHL- $a$ content in the mid-lake sediment treatment was slightly lower than what would be expected based on initial SRP concentrations (Fig. 5).

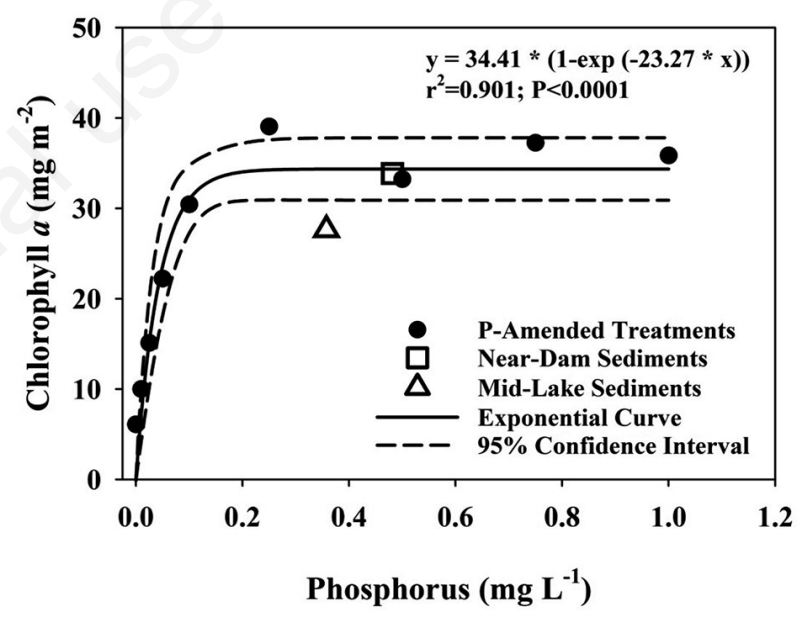

Fig. 5. Exponential growth curve of periphyton CHL- $a$ biomass across a gradient of increasing phosphorus concentrations measured after 6 days. Solid line represents the exponential growth curve model with dashed lines bracketing the $95 \%$ confidence interval. Lake sediment treatments are represented by open symbols.

Tab. 1. Mean sediment phosphorus-flux and final concentrations of soluble reactive phosphorus (SRP) from intact sediment cores collected from four locations in of Partners Lake in 2017. Linear regression statistics ( $\mathrm{r}^{2}$ and P values) reflect the mean change of SRP over time within each treatment $(n=3 /$ location and treatment).

\begin{tabular}{|c|c|c|c|c|c|c|c|}
\hline \multirow{3}{*}{$\begin{array}{l}\text { Location } \\
\text { Near-dam }\end{array}$} & \multirow{3}{*}{$\begin{array}{l}\text { Treatment } \\
\text { Aerobic }\end{array}$} & \multirow{3}{*}{0.870} & \multirow{3}{*}{0.006} & \multirow{2}{*}{\multicolumn{2}{|c|}{$\begin{array}{l}\text { Mean sediment } \\
\text { flux (range) } \mathrm{mg} \mathrm{m}^{-2} \mathrm{~d}-1\end{array}$}} & \multirow{2}{*}{\multicolumn{2}{|c|}{$\begin{array}{l}\text { Mean final } \\
\text { RP (range) } \mathrm{mg} \mathrm{L}^{-1}\end{array}$}} \\
\hline & & & & & & & \\
\hline & & & & 6.6 & $(1.6-18.6)$ & 0.34 & $(0.06-0.71)$ \\
\hline Near-dam & Anaerobic & 0.861 & $<0.001$ & 11.4 & $(1.1-29.7)$ & 0.64 & $(0.04-1.28)$ \\
\hline Mid-lake & Aerobic & 0.941 & $<0.001$ & 4.9 & $(1.4-10.1)$ & 0.18 & $(0.10-0.34)$ \\
\hline Mid-lake & Anaerobic & 0.964 & $<0.001$ & 16.0 & $(14.8-18.2)$ & 0.70 & $(0.64-0.84)$ \\
\hline Near-shore & Aerobic & 0.995 & $<0.001$ & 1.6 & $(0.3-4.3)$ & 0.08 & $(0.02-0.21)$ \\
\hline Inlet & Aerobic & 0.947 & 0.001 & 3.5 & $(1.7-7.2)$ & 0.11 & $(0.08-0.17)$ \\
\hline
\end{tabular}




\section{DISCUSSION}

\section{Site specific}

Nitrate-N concentrations were elevated in Partners Lake $\left(\sim 5.0 \mathrm{mg} \mathrm{L}^{-1}\right)$ relative to other small lakes in Northwest Arkansas (0.1 to $0.9 \mathrm{mg} \mathrm{L}^{-1} \mathrm{~N}$ ) (Scott and Grantz, 2013; Baker et al., 2018). These $\mathrm{NO}_{3}-\mathrm{N}$ concentrations were consistent with that expected in the cave-stream system based on the amount of human development in the watershed and recharge area (see Sharpley et al. 2017). However, SRP concentrations $\left(\sim 0.030 \mathrm{mg} \mathrm{L}^{-1}\right)$ entering Partners Lake were less than expected but within the range observed in other small lakes in the region ( 0.010 to 0.050 $\mathrm{mg} \mathrm{L}^{-1} \mathrm{P}$ ) (Baker et al., 2018).

This difference in the magnitude of the $\mathrm{NO}_{3}-\mathrm{N}$ and SRP concentrations resulted in DIN:SRP [molar] ratios ranging from 280 to over 8000 (Fig. 1E). These ratios are well above that considered optimal for phytoplankton and periphyton growth $(\mathrm{N}: \mathrm{P}=22)$ (Hillebrand and Sommer, 1999; Guildford and Hecky, 2000; Smith, 2003). This imbalance in DIN supply relative to SRP suggests phytoplankton and periphyton growth should be Plimited. As hypothesized, nutrient limitation assays supported the prediction that phytoplankton communities in Partner's lake are P-limited. Interestingly, phytoplankton communities from the inlet were not only P-limited but also co-limited by N, despite the prevailing P-limiting conditions in the water column (Fig. 3B).

We hypothesized that periphyton would also be Plimited based on the limited availability of $\mathrm{P}$ in the water column. Experimental units at the inlet and mid lake could not be used to support or refute our hypothesis due to metaphyton mats covering the nutrient diffusing substrates. However, findings from the dam site support the prediction that periphyton growth, higher in the water column, is P-limited (Fig. 3A).

NDS's deployed in the upper portion of the water column suggest P-limitation of periphyton growth; however, the periphyton community in the lake consists primarily of Spirogyra spp. (W.R. Green, personal communication), a filamentous green algae that forms floating masses anchored to the lake bottom (Gallego et al., 2013). While, Spirogyra specializes in high N low P environments (Townsend et al., 2008), the lowest molar ratio of $\mathrm{N}$ to $\mathrm{P}$ in the water column $(\mathrm{N}: \mathrm{P}=280)$ is much greater than what is optimal for its growth $(\mathrm{N}: \mathrm{P}=87$; Townsend et al., 2008). Furthermore, these findings suggest that water column DIN:SRP ratios likely do not represent the conditions above the sediments where periphyton is actively growing, nor complex interactions within the periphyton matrix where nutrients are recycled (Borchardt, 1996; Scott et al., 2007). When NDS are deployed just below the water's surface, they are assessing nutrient limitation of periphyton growth in the water column, which is not the same as the conditions at the sediment-water interface.

As hypothesized, aerobic P-flux's measured in from sediment cores collected in May were comparable to release rates measured in other lakes throughout the region $\left(<0.01\right.$ to $6 \mathrm{mg} \mathrm{m}^{-2} \mathrm{~d}^{-1}$ ) (Haggard and Soerens, 2006; Sen et al., 2007; Haggard et al., 2012; Lasater and Haggard, 2017; McCarty, 2020). With the low P concentrations in the water column of Partners Lake, the sediment may be the primary source of $\mathrm{P}$ driving nuisance periphyton growth. Spirogyra spp. has been found to grow better in the presence of sediments, especially when nutrients in the water column are limiting (Gallego et al., 2013). Specifically, sediments were identified as an essential source of $\mathrm{P}$ to benthic algal growth in natural systems (Townsend et al., 2008). Thus, P-flux from the sediments was probably determining the rate of periphyton growth since the $\mathrm{N}$ in the water column was high and bioassays indicated strongly P-limiting conditions. Additionally, since there were no seasonal increases in SRP, the periphyton were likely immobilizing this critically important resource as quickly as it was released from the sediments. Once immobilized, periphyton communities can retain and recycle nutrients very efficiently (Borchardt, 1996; Scott et al., 2007).

In the laboratory, $\mathrm{P}$ released from lake sediments maximized periphyton growth (Fig. 3). These findings support the hypothesis that $\mathrm{P}$ released from the sediments is sufficient to support nuisance algal growth. Overall, periphyton growth plateaued between 0.10 and $0.25 \mathrm{mg}$ $\mathrm{L}^{-1}$ of $\mathrm{P}$; this was similar to the range in final SRP concentrations in the overlying water of the aerobic cores. Scaling up the periphyton growth rate measured in the sediment treatments (i.e., $\sim 4 \mathrm{mg} \mathrm{m}^{-2} \mathrm{~d}^{-1}$ ) of the tile experiment to the growing season (i.e., March $1^{\text {st }}$ through October $31^{\text {st }}$ or 214 days) equates to $\sim 850 \mathrm{mg} \mathrm{m}^{-2} \mathrm{CHL}-$ $a$ produced, or roughly 6 times more biomass than what is considered nuisance conditions (see Suplee et al., 2009). This suggests that internal $P$ loading is capable of maximizing periphyton growth and supporting nuisance conditions in the lake, when $\mathrm{N}$ is not limiting, as measured here.

\section{Broader implications}

Currently, algaecides (i.e., $\mathrm{CuSO}_{4}$ ) are often used to control nuisance growth of primary producers in small eutrophic lakes, such as Partners Lake (McKnight et al., 1983; Hanson and Stefan, 1984), but this management approach addresses a symptom of accelerated eutrophication rather than the cause. Controlling the external loading of $\mathrm{P}$ from the watershed is often believed to be the most effective way at reducing nuisance phytoplankton growth (Schindler, 1977; Schindler et al., 
2008). However, previous work suggests that high internal P-loading from the sediments can sustain phytoplankton growth in lakes even following reductions in external loading (Søndergaard et al., 2003, 2013; Steinman et al., 2009).

Like phytoplankton, periphyton communities in shallow lakes rely on both internal and external P loads. However, periphyton can also alter the local chemical environment allowing for increased P-release. Respiration at night can drive down DO increasing P-flux (Dodds, 2003), and while increased photosynthesis during the day produces $\mathrm{DO}$, it can also increase the local $\mathrm{pH}$, which releases $\mathrm{P}$ from $\mathrm{Fe} / \mathrm{Al}$ complexes (Lu et al., 2016). The release of SRP from sediments can promote and sustain nuisance periphyton growth, especially when the $\mathrm{N}$ supply is abundant in the water column. For these reasons, managing the pool of legacy $P$ in the sediments of shallow lakes may be just as important, if not more, for controlling excessive periphyton growth as it is for controlling phytoplankton growth.

P-inactivation or prevention of P-release from the sediments through capping may be a possible solution. Application of aluminum sulfate (alum) in the lake has the potential to reduce sediment P-flux by up to $85 \%$ and reduce $\mathrm{P}$ concentrations in the water column (Huser et al., 2011). Another possible tool is Lanthanum-modified bentonite clay (Phoslock $\left.{ }^{\circledR}\right)$, which works by increasing the sediment P-sorption capacity, effectively capping the sediments and preventing the release of $\mathrm{P}$ to the water column (Meis et al., 2012). We know that both alum and Phoslock ${ }^{\circledR}$ reduce sediment P-release, the next question to consider is whether these products can be used to effectively manage nuisance conditions, through reducing internal P-loading.

\section{CONCLUSIONS}

This study provides essential information about Partners Lake and why the nuisance periphyton conditions persist, which can be boiled down to three main points: i) Both phytoplankton and periphyton were P-limited based on the water chemistry and nutrient limitation assays. However, this may not be the case for periphyton growth at the sediment-water interface; ii) The watershed and recharge area of the lake contributes a lot of $\mathrm{N}$ in the form of $\mathrm{NO}_{3}-\mathrm{N}$ and not much $\mathrm{P}$, but the lake sediments are a significant source of dissolved $\mathrm{P}$; iii) The nuisance periphyton growth in Partners Lake results from internal P-release from the sediments and the external $\mathrm{N}$ inputs.

Moving forward, we need to begin managing not only the $\mathrm{P}$ that is applied and transported from the landscape, but also the legacy $\mathrm{P}$ that is stored in the sediments of our waterbodies. It is unlikely that reductions in external $\mathrm{P}$ inputs to the system would have any effect controlling nuisance growth, if sediments are meeting the periphyton community's demand for P.

\section{REFERENCES}

APHA 2014. Standard Methods for examination of water and wastewater. 22nd ed. American Public Health Association, Washington: $1360 \mathrm{pp}$.

Ashley K, Cordell D, Mavinic D, 2011. A brief history of phosphorus: from the philosopher's stone to nutrient recovery and reuse. Chemosphere 84:737-746.

Baker BC, Wilson AE, Scott JT, 2018. Phytoplankton N2fixation efficiency and its effect on harmful algal blooms. Freshw. Sci. 37:264-275.

Borchardt M, 1996. Nutrients. In: Stevenson RJ, M Bothwell, and RL Lowe (eds.), Algal Ecology. Freshwater Benthic Ecosystems, San Diego, CA: Academic Press.

Brennan RB, Scott JT, Sharpley AN, Lally HT, Jarvie HP, Bowes MJ, Haggard BE, Gbur E, 2017. Linking Soil Erosion to Instream Dissolved Phosphorus Cycling and Periphyton Growth. J. Am. Water Resour. Assoc. 53:809-821.

DeSimone LA, Hamilton PA, 2009. Quality of Water from Domestic Wells in Principal Aquifers of the United States, 1991-2004. US Department of the Interior, US Geological Survey.

Dodds WK, 2003. The role of periphyton in phosphorus retention in shallow freshwater aquatic systems. J. Phycol. 39:840-849.

Elosegi A, Pozo J, 2016. Altered organic matter dynamics in rivers and streams: ecological consequences and management implications. Limnetica 35:303-322.

Gallego IN, Casas JJ, Sánchez-Castillo P, Fuentes-Rodríguez F, Juan M, Pérez-Martínez C, 2013. Culture of Spirogyra africana from farm ponds for long-term experiments and stock maintenance. Biotechnol. Agron. Société Environ. 17:423-430.

Grantz EM, Haggard BE, Scott JT, 2014. Stoichiometric imbalance in rates of nitrogen and phosphorus retention, storage, and recycling can perpetuate nitrogen deficiency in highlyproductive reservoirs. Limnol. Oceanogr. 59:2203-2216.

Guildford SJ, Hecky RE, 2000. Total nitrogen, total phosphorus, and nutrient limitation in lakes and oceans: Is there a common relationship? Limnol. Oceanogr. 45:1213-1223.

Haggard BE, Scott JT, Patterson S, 2012. Sediment phosphorus flux in an Oklahoma reservoir suggests reconsideration of watershed management planning. Lake Reserv. Manag. 28:59-69.

Haggard BE, Smith DR, Brye KR, 2007. Variations in Stream Water and Sediment Phosphorus among Select Ozark Catchments. J. Environ. Qual. 36:1725.

Haggard BE, Soerens TS, 2006. Sediment phosphorus release at a small impoundment on the Illinois River, Arkansas and Oklahoma, USA. Ecol. Eng. 28:280-287.

Hanson MJ, Stefan HG, 1984. Side effects of 58 years of copper sulfate treatment of Fairmont Lakes, Minnesota. JAWRA J. Am. Water Resour. Assoc. 20:889-900.

Hillebrand H, Sommer U, 1999. The nutrient stoichiometry of benthic microalgal growth: Redfield proportions are optimal. Limnol. Oceanogr. 44:440-446. 
Huser B, Brezonik P, Newman R, 2011. Effects of alum treatment on water quality and sediment in the Minneapolis Chain of Lakes, Minnesota, USA. Lake Reserv. Manag. 27:220-228.

Jarvie HP, Sharpley AN, Spears B, Buda AR, May L, Kleinman PJA, 2013. Water quality remediation faces unprecedented challenges from "legacy Phosphorus." Environ. Sci. Technol. 47:8997-8998.

Johnson LT, Tank JL, Dodds WK, 2009. The influence of land use on stream biofilm nutrient limitation across eight North American ecoregions. Can. J. Fish. Aquat. Sci. 66:1081-1094.

Lasater AL, Haggard BE, 2017. Sediment Phosphorus Flux at Lake Tenkiller, Oklahoma: How Important Are Internal Sources? Agric. Environ. Lett. 2.

Lu H, Wan J, Li J, Shao H, Wu Y, 2016. Periphytic biofilm: A buffer for phosphorus precipitation and release between sediments and water. Chemosphere 144:2058-2064.

Ludwig A, Matlock M, Haggard B, Chaubey I, 2012. Periphyton Nutrient Limitation and Maximum Potential Productivity in the Beaver Lake Basin, United States 1. J. Am. Water Resour. Assoc. 48:896-908.

Maberly SC, King L, Dent MM, Jones RI, Gibson CE, 2002. Nutrient limitation of phytoplankton and periphyton growth in upland lakes. Freshw. Biol. 47:2136-2152.

Matlock MD, Matlock ME, Storm DE, Smolen MD, Henley WJ, 1998. Limiting nutrient determination in lotic ecosystems using a quantitative nutrient enrichment peripphytometer. J. Am. Water Resour. Assoc. 34:1141-1147.

McCarty JA, 2020. Algal demand drives sediment phosphorus release in a shallow eutrophic cove. Trans. ASABE. 62: 1315-1324.

McKnight DM, Chisholm SW, Harleman DRF, 1983. CuSO 4 treatment of nuisance algal blooms in drinking water reservoirs. Environ. Manage. 7:311-320.

Meis S, Spears BM, Maberly SC, O’Malley MB, Perkins RG, 2012. Sediment amendment with Phoslock ${ }^{\circledR}$ in Clatto Reservoir (Dundee, UK): investigating changes in sediment elemental composition and phosphorus fractionation. J. Environ. Manage. 93:185-193.

Mortimer CH, 1971. Chemical Exchanges Between Sediments an Water in The Great Lakes-Speculations on Probable Regulatory Mechanisms. Limnol. Oceanogr. 16:387-404.

Müller S, Mitrovic SM, 2015. Phytoplankton co-limitation by nitrogen and phosphorus in a shallow reservoir: progressing from the phosphorus limitation paradigm. Hydrobiologia 744:255-269.

Paerl HW, Scott JT, McCarthy MJ, Newell SE, Gardner WS, Havens KE, Hoffman DK, Wilhelm SW, Wurtsbaugh WA, 2016. It Takes Two to Tango: When and Where Dual Nutrient (N \& P) Reductions Are Needed to Protect Lakes and Downstream Ecosystems. Environ. Sci. Technol. 50:10805-10813.

Reddy KR, Diaz OA, Scinto LJ, Agami M, 1995. Phosphorus dynamics in selected wetlands and streams of the Lake Okeechobee Basin. Ecol. Eng. 5:183-207.

Schindler DW, 1977. Evolution of phosphorus limitation in lakes. Sci. 195:260-262.

Schindler DW, Hecky RE, Findlay DL, Stainton MP, Parker BR,
Paterson MJ, Beaty KG, Lyng M, Kasian SEM, 2008. Eutrophication of lakes cannot be controlled by reducing nitrogen input: results of a 37-year whole-ecosystem experiment. Proc. Natl. Acad. Sci. 105:11254-11258.

Scott JT, Doyle RD, Back JA, Dworkin SI, 2007. The role of N 2 fixation in alleviating $\mathrm{N}$ limitation in wetland metaphyton: enzymatic, isotopic, and elemental evidence. Biogeochemistry 84:207-218.

Scott JT, Doyle RD, Filstrup CT, 2005. Periphyton nutrient limitation and nitrogen fixation potential along a wetland nutrient-depletion gradient. Wetlands 25:439-448.

Scott JT, Grantz EM, 2013. N2 fixation exceeds internal nitrogen loading as a phytoplankton nutrient source in perpetually nitrogen-limited reservoirs. Freshw. Sci. 32:849-861.

Sen S, Haggard BE, Chaubey I, Brye KR, Costello TA, Matlock MD, 2007. Sediment Phosphorus Release at Beaver Reservoir, Northwest Arkansas, USA, 2002-2003: A Preliminary Investigation. Water. Air. Soil Pollut. 179:67-77.

Sharpley A, Jarvie HP, Buda A, May L, Spears B, Kleinman P, 2013. Phosphorus Legacy: Overcoming the Effects of Past Management Practices to Mitigate Future Water Quality Impairment. J. Environ. Qual. 42:1308-1326.

Sharpley AN, Haggard BE, Berry L, Brye K, Burke J, Daniels MB, Gbur E, Glover T, Hays P, Kresse T, VanDevender KW, 2017. Nutrient Concentrations in Big Creek Correlate to Regional Watershed Land Use. Agric. Environ. Lett. 2.

Smith VH, 2003. Eutrophication of freshwater and coastal marine ecosystems a global problem. Environ. Sci. Pollut. Res. 10:126-139.

Smith VH, Tilman GD, Nekola JC, 1999. Eutrophication: impacts of excess nutrient inputs on freshwater, marine, and terrestrial ecosystems. Environ. Pollut. 100:179-196.

Søndergaard M, Bjerring R, Jeppesen E, 2013. Persistent internal phosphorus loading during summer in shallow eutrophic lakes. Hydrobiologia 710:95-107.

Søndergaard M, Jensen JP, Jeppesen E, 2003. Role of sediment and internal loading of phosphorus in shallow lakes. Hydrobiologia 506:135-145.

Steinman A, Chu ÆX, Ogdahl ÆM, 2009. Spatial and temporal variability of internal and external phosphorus loads in Mona Lake, Michigan. 1-18.

Stevenson RJ, 1996. An introduction to algal ecology in freshwater benthic habitats. In: Stevenson RJ, M Bothwell, R Lowe (eds.), Algal Ecology. Freshwater Benthic Ecosystems, San Diego, CA: Academic Press. p. 3-30.

Suplee MW, Watson V, Teply M, McKee H, 2009. How Green is Too Green? Public Opinion of What Constitutes Undesirable Algae Levels in Streams 1. J. Am. Water Resour. Assoc. 45:123-140.

Townsend SA, Schult JH, Douglas MM, Skinner S, 2008. Does the Redfield ratio infer nutrient limitation in the macroalga Spirogyra fluviatilis? Freshw. Biol. 53:509-520.

Zhu W, Zhou X, Chen H, Gao L, Xiao M, Li M, 2016. High nutrient concentration and temperature alleviated formation of large colonies of Microcystis: evidence from field investigations and laboratory experiments. Water Res. 101:167-175. 